\title{
Safety and efficacy of clonidine and clonidine extended-release in the treatment of children and adolescents with attention deficit and hyperactivity disorders
}

REVIEW

Xue Ming'

Martha Mulvey'

Sharanya Mohanty ${ }^{2}$

Viraj Patel ${ }^{2}$

'Department of Neurosciences, University of Medicine and Dentistry New Jersey, New Jersey Medical School, Newark; ${ }^{2}$ The College of New Jersey, Ewing, NJ, USA
This article was published in the following Dove Press journal:

Adolescent Health, Medicine and Therapeutics

29 September 2011

Number of times this article has been viewed
Correspondence: Xue Ming

90 Bergen Street, DOC 8100,

UMDNJ, New Jersey Medical School,

Newark, NJ 07 I03, USA

Tel +l 9739722922

Fax + I 9739729553

Email mingxu@umdnj.edu
Abstract: Clonidine has been used off-label in children and adolescents with attention deficit and hyperactivity disorders (ADHD) with or without comorbidities. Clonidine extended-release was recently approved by the US Food and Drug Administration for ADHD in children. This review evaluates the efficacy and safety of clonidine extended-release and clonidine in children and adolescents with ADHD. A search of the Medline database and clinical trials register from 1996-2011 yielded ten clinical trials for critical evaluation of efficacy and safety. Eight of the ten trials reviewed were double-blinded and placebo-controlled. Nine of the ten trials utilized multiple outcome measures. Both clonidine extended-release and clonidine, as monotherapy or adjunctive therapy, were reported to be efficacious in treating ADHD symptoms in children and adolescents with or without comorbid disorders in nine of the ten clinical trials. One study showed clonidine to be ineffective in improving performance of a single task, at a specific point in time, in a small number of subjects. All of the studies that evaluated safety reported clonidine and clonidine extended-release to be well tolerated. The side effects of clonidine included somnolence, fatigue, headache, bradycardia, hypotension, and clinically insignificant electrocardiographic changes. However, there are historical anecdotal reports of serious cardiac side effects, including death in cases with other risk factors. None of the studies compared clonidine extended-release with clonidine in subjects with ADHD. Therefore, it is not clear whether clonidine extended-release is advantageous over clonidine, with regard to either efficacy or safety. It is equally unclear whether clonidine or clonidine extended-release is more efficacious in treating ADHD in subjects with comorbid disorders than in those without comorbidities. All the studies reviewed had limitations in their designs and methods. Clonidine and clonidine extended-release could be efficacious and safe for the treatment of ADHD both as monotherapy and as adjunctive therapy with stimulant medications in selected patients. There is a need for clinical trials to determine the long-term efficacy and safety of treatment with clonidine and clonidine extended-release in patients with ADHD.

Keywords: attention deficit and hyperactivity disorders, clonidine extended-release, clonidine, comorbidity, safety, efficacy, children

\section{Introduction}

Attention deficit hyperactivity disorder (ADHD) is reported to be one of the most commonly diagnosed childhood behavioral disorders, which can often continue through adolescence and adulthood, according to the National Institutes of Health. ${ }^{1}$ Previous research reports the prevalence rate of this disorder to be $1.7 \%-16 \%{ }^{2}$ ADHD is 
reported to be diagnosed much more frequently in males than in females and the symptoms of ADHD are frequently seen with comorbid disorders (eg, oppositional defiant disorders, conduct disorder, tic disorder, anxiety). ${ }^{2,3}$

Commonly known core symptoms for ADHD include inattention, hyperactivity, and impulsivity. ${ }^{1,4}$ Behavioral criteria provided by the Diagnostic and Statistical Manual of Mental Disorders (DSM-IV) serves as one of the most widely used tools for diagnosis. ${ }^{1,4,5}$ Treatment for ADHD has included the use of psychostimulants, centrally acting alpha-2 adrenergic agonists, tricyclic antidepressants, and antipsychotics. ${ }^{1}$ Many clinicians use medications to control the symptoms of ADHD and its comorbidity. Psychostimulants alone have not been effective in controlling sympathetic hyperarousable states of ADHD and comorbidities. Clonidine, as an adjunct to a psychostimulant, significantly enhances effectiveness in optimizing daily function and performance in patients with ADHD. ${ }^{6}$

Most pharmacological treatments for ADHD facilitate catecholaminergic transmission, ${ }^{7}$ especially in the prefrontal cortex. ${ }^{8}$ Alpha-2 adrenergic agonists, such as clonidine, modulate sympathetic tone by increasing noradrenergic outflow from the locus ceruleus to the prefrontal cortex and by direct stimulation of presynaptic alpha-2A receptors in the cortex. The resulting increase in noradrenergic sympathetic transmission potentiates dorsolateral prefrontal cortical function, and leads to the increased regulation of attention and behavior. ${ }^{9}$ The hypothalamic-pituitaryadrenal axis works in concert with the catecholamine system in regulating attention and memory in animals. ${ }^{10-12}$ Coactivation of the noradrenergic sympathetic system with stress hormones enhances spatial memory function and provides positive feedback to the hypothalamic-pituitaryadrenal axis. ${ }^{13}$

Additionally, clonidine stimulates alpha-2A adrenergic receptors in the brain stem. As a result, sympathetic outflow from the central nervous system is reduced, leading to a decrease in peripheral resistance, renal vascular resistance, heart rate, and blood pressure. ${ }^{14}$ In clinical practice, clonidine has been used off-label for the treatment of ADHD and comorbidities. The use of clonidine extended-release for the treatment of ADHD as monotherapy or a therapy adjunctive to stimulant medications was approved by the US Food and Drug Administration in 2010. ${ }^{14}$ Clonidine extended-release has been approved for children aged 6-17 years with ADHD, given twice per day at a dose of $0.1-0.4 \mathrm{mg} /$ day.

Clonidine has been used to treat ADHD for many years. The efficacy and safety of clonidine extended-release has not been extensively evaluated. This review aims to identify and evaluate the efficacy and safety of clonidine extended-release in ADHD and its comorbidities. Efforts were made to discover studies comparing clonidine with clonidine extended-release.

\section{Methods}

The PubMed and Ovid search engines were utilized with the Medline database from 1996 to July 2011 to identify articles regarding the efficacy and safety of clonidine extendedrelease and clonidine in children and adolescents with ADHD under the age of 18 years. The search was conducted using the keywords "clonidine", "treatment", "safety", and "attention deficit hyperactivity disorder". A search for registered clinical trials using clonidine for ADHD within clinicaltrials.gov was also conducted. These keywords produced 140 articles from PubMed, and 64 articles from Ovid which were also included in PubMed. Abstracts and titles were reviewed, and only those articles that focused on assessment of the efficacy and safety of clonidine used for ADHD were reviewed in full text. Clinical trials addressing the efficacy and safety of clonidine and clonidine extendedrelease alone or in combination with a stimulant for children and adolescents with ADHD and other comorbid behavioral disorders were summarized.

Studies in animals and foreign language articles were excluded from the review. Studies that used alternative medications in conjunction with clonidine in treating patients with ADHD were also excluded. We reviewed original clinical trials, review articles, and case studies to assess and analyze how effective and safe clonidine and clonidine extendedrelease are when treating patients with ADHD. The results are reported as follows.

\section{Efficacy}

Clonidine has been reported to be efficacious in treating ADHD symptoms in children and adolescents. Two Phase III, eight-week trials of double-blinded, placebo-controlled studies investigated the efficacy and safety of clonidine extended-release in ADHD children aged 6-17 years. Jain et al ${ }^{15}$ used a fixed final daily dose of $0.2 \mathrm{mg}$ or $0.4 \mathrm{mg}$ in 143 subjects who were not taking any form of psychostimulants. A dose-escalating titration of $0.1 \mathrm{mg} /$ day was utilized to the final target doses over four weeks. The researchers used the following tools to evaluate efficacy: ADHD-RS-IV, Conner's Parent Rating Scale-Revised: Long Form (CPRS-R), Clinical Global Impression of Severity (CGI-S) scale, Clinical Global Impression of Improvement 
(CGI-I), and the Parent Global Assessment (PGA) scale. Significant clinical improvement occurred in both clonidine extended-release dosage groups on total score for the ADHDRS-IV scale by week 5 and was maintained throughout the entire eight-week treatment period. Inattention, hyperactivity, and impulsivity subscale scores on the ADHDRS-IV demonstrated significant improvement. Similarly, improvement in CPRS-R was significantly greater in the clonidine extended-release treated groups. In addition, the CGI-S and CGI-I scales showed greater improvement in both clonidine extended-release groups versus the placebo group. Improvement of behavior in the two clonidine extendedrelease dosage groups was overlapping, suggesting that the higher dose did not yield additional efficacy. The strength of this study was the use of clonidine extended-release without the interference of psychostimulants. This study allowed inclusion of tic disorders and oppositional defiant disorders. However, the authors did not indicate how many of the subjects with these comorbid disorders were included. There was a high dropout rate of subjects, rendering the study population prone to bias.

The other study by Kollins et $\mathrm{al}^{16}$ examined clonidine extended-release as an add-on therapy to existing psychostimulants in children with ADHD in a multicenter, eight-week clinical trial. They initiated clonidine extendedrelease or placebo in children who were already taking a psychostimulant. The clonidine extended-release dose was a flexible escalation regardless of subject age or body weight; the dose was titrated up based on the subject response (it is not clear how responses were evaluated for the titration). The existing stimulants were diverse and of either the methylphenidate or amphetamine categories. The physicians were allowed to adjust the stimulant dosages without changing the stimulant category during the trial. The study used ADHD rating scales and other psychological instruments completed by researchers and parents. Improvements in ADHD rating scores from baseline and after the add-ons were used to compare the efficacy of clonidine extendedrelease versus placebo. The clonidine extended-release dose and administration were flexible. The researchers reported a significantly greater improvement in ADHD rating scales in the clonidine extended-release add-on group as compared with placebo and the existing psychostimulant. The improvement started at week 2, reached a maximal level at weeks 4-5, and was maintained until week 7 of the trial. However, there was no significant difference between the two groups at week 8 . The investigators reported that a greater number of subjects in the clonidine extended-release group reduced their psychostimulant doses than in the placebo group. This study showed that clonidine extended-release was efficacious as an add-on in children who had a partial response to psychostimulants. The strength of this study, like the study of Jain et al, ${ }^{15}$ was its double-blind, placebo-controlled multicenter design. Multiple psychological instruments were utilized, and the interindividual variation was minimized by measuring improvement within the same individuals. However, the experimental design was complicated with too many variables. The varying clonidine extended-release dose and administration frequency, along with the changing psychostimulant doses, makes interpretation of the results difficult.

Both Jain et $\mathrm{al}^{15}$ and this study ${ }^{16}$ did not perform a comparison of clonidine extended-release with clonidine, providing no information as to whether the extended-release is a better formula. One additional study is registered at clinicaltrial.gov for clonidine extended-release safety in children and adolescents with ADHD. No articles describing this study were available.

Three additional double-blind, placebo-controlled studies ${ }^{17-19}$ on clonidine efficacy in children and adolescents are included in Table 1. Two of the three studies ${ }^{17,18}$ appear to originate from a subpopulation of the same cohort. Palumbo et $\mathrm{al}^{17}$ reported the efficacy of clonidine in the improvement of ADHD symptom scales in subjects, while Cannon et $\mathrm{al}^{19}$ reported efficacy in improvement of quality of life in families of ADHD children on clonidine treatment. The subjects were administered clonidine, methylphenidate, clonidine and methylphenidate, or placebo. The daily average dose of clonidine was $0.24 \pm 0.11 \mathrm{mg}$, while the maximal dose was $0.6 \mathrm{mg}$. Clonidine was given in a 3-4 times daily dose regimen. Palumbo et $\mathrm{al}^{17}$ reported greater improvements in Conner's scale rated by parents in the clonidine-treated groups versus placebo in 78 subjects who completed the study. However, teachers of the subjects reported no significant improvement in the same efficacy measures as the ones completed by parents when it came to treatment with clonidine. Cannon et $\mathrm{al}^{19}$ reported improvement in quality of family life compared with the treatment groups as a whole versus placebo.

Five articles ${ }^{20-24}$ reported the efficacy of clonidine alone or in combination with methylphenidate in children and adolescents with ADHD and other comorbid behavioral disorders, including tic disorders, conduct disorders, oppositional defiant disorders, anxiety disorders, and seizures (Table 2). Kurlan et $\mathrm{al}^{20}$ conducted a clinical trial in children with ADHD and chronic tic disorder. Subjects were 
Table I Double-blind, placebo-controlled, clinical trials of clonidine in children and adolescents with ADHD

\begin{tabular}{|c|c|c|c|c|c|c|c|}
\hline Authors & $\begin{array}{l}\text { Subjects } \\
\text { enrolled } \\
\text { (completed) }\end{array}$ & Design & $\begin{array}{l}\text { CLO daily } \\
\text { dose }\end{array}$ & $\begin{array}{l}\text { Efficacy } \\
\text { measures }\end{array}$ & $\begin{array}{l}\text { Safety } \\
\text { measures }\end{array}$ & Efficacy & Side effects \\
\hline Jain et $\mathrm{al}^{15}$ & $236(143)$ & $\begin{array}{l}\text { 8-week, } \\
\text { two dosage } \\
\text { CLO ER groups } \\
\text { versus placebo }\end{array}$ & $0.2 \mathrm{mg}, 0.4 \mathrm{mg}$ & $\begin{array}{l}\text { Multiple ADHD } \\
\text { RS and psychological } \\
\text { tests by researchers } \\
\text { and parents }\end{array}$ & $\begin{array}{l}\text { Clinical report, } \\
\text { ECG, VS, } \\
\text { laboratory } \\
\text { tests }\end{array}$ & $\begin{array}{l}\text { Significantly } \\
\text { greater } \\
\text { improvement in } \\
\text { both CLO ER } \\
\text { dosage groups } \\
\text { versus placebo }\end{array}$ & $\begin{array}{l}\text { Somnolence } \\
\text { Fatigue }\end{array}$ \\
\hline Kollins et a ${ }^{16}$ & $198(165)$ & $\begin{array}{l}\text { 8-week, CLO } \\
\text { ER add-on versus } \\
\text { placebo }\end{array}$ & $\begin{array}{l}\text { Escalating doses, } \\
\max 0.4 \mathrm{mg}\end{array}$ & $\begin{array}{l}\text { Multiple ADHD } \\
\text { RS and psychological } \\
\text { tests by researchers } \\
\text { and parents }\end{array}$ & $\begin{array}{l}\text { Clinical report, } \\
\text { ECG, VS }\end{array}$ & $\begin{array}{l}\text { CLO ER } \\
\text { efficacious as } \\
\text { an add-on in } \\
\text { children with } \\
\text { partial response } \\
\text { to stimulants }\end{array}$ & $\begin{array}{l}\text { Somnolence } \\
\text { Headache } \\
\text { Fatigue }\end{array}$ \\
\hline Palumbo et al ${ }^{17}$ & $122(78)$ & $\begin{array}{l}\text { I6-week, CLO, } \\
\text { MLP, CLO + } \\
\text { MLP, placebo }\end{array}$ & $\begin{array}{l}\text { Mean } 0.24 \pm \\
0.11 \mathrm{mg} \\
\text { Max } 0.6 \mathrm{mg}\end{array}$ & $\begin{array}{l}\text { ADHD RS by } \\
\text { teachers and } \\
\text { parents }\end{array}$ & $\begin{array}{l}\text { Clinical report, } \\
\text { ECG, VS }\end{array}$ & $\begin{array}{l}\text { CLO better } \\
\text { than placebo by } \\
\text { parents reports, } \\
\text { but not by } \\
\text { teachers' reports }\end{array}$ & Sedation \\
\hline Daviss et al ${ }^{18}$ & 122 & $\begin{array}{l}\text { I6-week, CLO, } \\
\text { MLP, CLO + } \\
\text { MLP, placebo }\end{array}$ & $\begin{array}{l}\text { Titration } \\
\max 0.6 \mathrm{mg}\end{array}$ & N/A & $\begin{array}{l}\text { Clinical report, } \\
\text { Pittsburgh side } \\
\text { effect RS, ECG, } \\
\text { VS }\end{array}$ & $\mathrm{N} / \mathrm{A}$ & $\begin{array}{l}\text { Somnolence } \\
\text { Nervousness } \\
\text { Bradycardia }\end{array}$ \\
\hline Cannon et al ${ }^{19}$ & $122(84-99)$ & $\begin{array}{l}\text { I6-week, CLO, } \\
\text { MLP, CLO + } \\
\text { MLP, placebo }\end{array}$ & $\begin{array}{l}\text { Mean } 0.24 \pm \\
0.11 \mathrm{mg} \\
\text { Max } 0.6 \mathrm{mg}\end{array}$ & $\begin{array}{l}\text { Questionnaires } \\
\text { by parents and } \\
\text { ADHD RS by } \\
\text { researchers }\end{array}$ & $\mathrm{N} / \mathrm{A}$ & $\begin{array}{l}\text { CLO + MLP } \\
\text { better than } \\
\text { placebo }\end{array}$ & $\mathrm{N} / \mathrm{A}$ \\
\hline
\end{tabular}

Abbreviations: ADHD, attention deficit and hyperactivity disorders; CLO, clonidine; ECG, electrocardiogram; ER, extended-release; max, maximum; MLP, methylphenidate; N/A, not available; RS, rating scales; ECG, electrocardiogram; VS, vital sign.

randomly given clonidine, methylphenidate, clonidine with methylphenidate, or placebo for a 16-week period. The average daily dose was $0.25 \mathrm{mg}$ for the group treated with clonidine and $0.28 \mathrm{mg}$ for the group treated with both clonidine and methylphenidate. The daily dose was adjusted according to subject response. The Conner's scales for teachers and parents elicited a significant treatment effect in the clonidine combined with methylphenidate group. This group was rated as the most effective for ADHD. Impulsivity and hyperactivity improved with clonidine as compared with placebo. Clonidine showed efficacy in children with ADHD and tics. Meere et $\mathrm{al}^{21}$ tested the efficacy of clonidine in children with ADHD using a GO-NO GO task to determine whether there was an improvement in state dysregulation. Similar to methylphenidate, clonidine was not effective. This study did not use psychological instruments and enrolled only 53 total subjects (17-18 subjects per group). The behavioral testing is a snapshot of the task performance that may be potentially biased by temporal factors and may not represent overall performance or improvement.

All of these five studies ${ }^{20-24}$ included comorbid conditions. Therefore, it is unclear whether the improvement in ADHD symptoms can be attributed to improvement of comorbidity with use of clonidine. Clonidine is an alpha-2 adrenergic agonist that can also be used for sympathetic hyperarousable states in other disorders, such as anxiety disorders ${ }^{25-39}$ and tic disorders. ${ }^{40-50}$ Four of the five studies ${ }^{21-24}$ had multiple comorbid disorders, making interpretation of the effect of clonidine on ADHD symptoms even more difficult. Likewise, it is also not clear whether clonidine is more effective in treating ADHD symptoms in subjects with ADHD and a comorbid disorder, given that none of the clinical trials reviewed were designed to compare clonidine in subjects with and without comorbidities.

Furthermore, almost all of the studies contained design limitations which included high dropout rates, multiple variables assessed, and relatively short study durations. All of the studies, except for one, were short-term, providing little information on the long-term effects of clonidine use. Therefore, lack of long-term data prevents us from drawing conclusions regarding the long-term efficacy of treatment with this medication.

Although each of the studies did report some form of improvement in the behavior of the patients enrolled, 
there exists variability, including heterogeneous subject populations, variable dosages and length of treatment, comorbid conditions, and different outcome measures between the studies. Outcomes among the studies are not comparable with one another, and it is premature to try to ascertain exactly which patients benefited from clonidine.

Overall, the findings of the studies suggest that clonidine and/or clonidine extended-release could be efficacious in the treatment of ADHD. However, it is important to note that the studies do contain significant limitations. Based on the findings, it is reasonable to conclude that patients suffering from ADHD and ADHD with comorbidities may potentially benefit from either treatment with clonidine or clonidine extended-release in the form of monotherapy or in conjunction with psychostimulants. A slow titration to an optimal dosage is recommended for patients with ADHD with or without comorbidities.

\section{Safety}

In general, clonidine and clonidine extended-release were reported to be safe and well tolerated in children and adolescents. Jain et $\mathrm{al}^{15}$ reported an overall general tolerance to clonidine extended-release. Somnolence and fatigue were the predominant side effects reported. There was no difference of prevalence of side effects in the two dosage groups. However, the number of subjects who discontinued clonidine extended-release was greatest in the higher-dose group ( $0.4 \mathrm{mg}$ daily), and the most common reasons for discontinuation were somnolence and fatigue. There were electrocardiographic changes in QT and PR intervals, but these were clinically insignificant. Heart rate and blood pressure were lower in the clonidine extended-release groups treated with the extended-release formulation. No significant laboratory changes were reported.

Kollins et $\mathrm{al}^{16}$ reported that a maximal daily clonidine extended-release dose of $0.4 \mathrm{mg}$ was well tolerated in their cohort, although somnolence, headache, fatigue, and slight changes in QT intervals were higher in prevalence in the clonidine extended-release plus stimulant group. However, it is not possible to attribute the reported side effects to clonidine extended-release alone, because stimulants were also used. Palumbo et $a{ }^{17}$ reported transient sedation that was tolerated by a majority of subjects. No electrocardiographic changes were found. In this study, clonidine was given in 3-4 divided doses. This fact may be a potential explanation for the lower prevalence of side effects. Daviss et $\mathrm{al}^{18}$ analyzed all 122 subjects from the same cohort as Palumbo et $\mathrm{al}^{17}$ and reported that bradycardia was significantly more common in patients treated with clonidine. A greater increase in orthostatic systolic blood pressure was reported as significant in the subjects taking clonidine. Somnolence, nervousness, and fatigue were more prevalent in the clonidine-treated groups. Eight subjects withdrew from the study due, at least in part, to the side effects. Although there were electrocardiographic changes, the only significant finding among the groups was bradycardia in the clonidine-treated groups. The remaining clinical trials ${ }^{20-24}$ reported similar side effects, such as sedation, somnolence, bradycardia, and electrocardiographic changes. Most of the clinical trials reported transience or tolerability of these side effects. It is not clear whether clonidine extended-release is better tolerated than clonidine, because clonidine extended-release was not compared with clonidine alone in any of the studies reviewed.

A case study ${ }^{51}$ of an eleven-year-old with a tic disorder reported a transient ischemic attack while taking risperidone and clonidine. It is not clear whether the medications, or which of the two medications, caused the transient ischemic attack. Another case study ${ }^{52}$ reported new onset of seizure in a nine-year-old girl with ADHD who was taking clonidine. However, this patient had other potential etiologies for seizures. Long-term side effects were not assessed by any of the studies reviewed.

None of the clinical trials included in this review reported any serious or fatal side effects of treatment with clonidine or clonidine extended-release. However, there have been some concerns regarding cardiac toxicity and the use of these medications. ${ }^{53-57}$ Maloney and Schwam described three unpublished cases of death associated with clonidine and methylphenidate use. These children had other comorbidities which confounded their deaths. They also discussed five other cases of cardiac complications while taking clonidine..$^{53}$ The electrocardiographic changes returned to normal when the dosage of clonidine was lowered or discontinued. Fenichel ${ }^{57}$ described three of the four children with cardiac side effects who died while taking clonidine with methylphenidate. All of the three cases had other etiological confounders that could explain the deaths. Cantwell et al ${ }^{54}$ described one death in a child with a congenital cardiac malformation when taking clonidine. While the exact contribution of clonidine to the serious side effects described in these cases cannot be ascertained, serious cardiac side effects can occur, especially in individuals with coexisting cardiac or noncardiac risk factors. Periodic monitoring for cardiac side effects with clonidine is advised. 


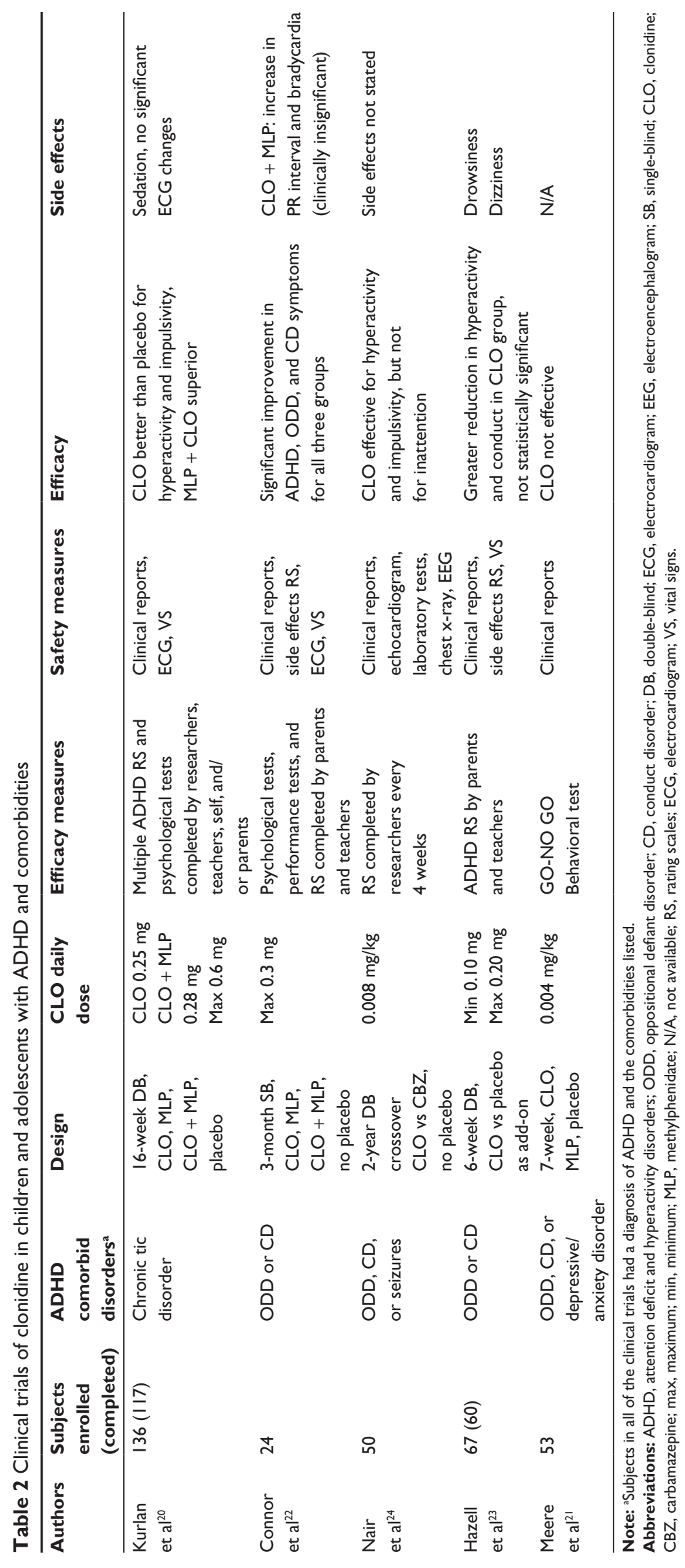




\section{Summary}

Clonidine and clonidine extended-release have been shown to have efficacy in the treatment of ADHD. However, the studies contain significant flaws. Patients with ADHD, especially those with comorbidities, require individualized treatment. Clonidine may be efficacious, and is worth trying in patients as monotherapy or as combination therapy.

Improvement in inattention, impulsivity, and hyperactivity has been reported. No additional benefit in improvement of ADHD symptoms was noted with higher doses of clonidine or clonidine extended-release. It is not evident whether clonidine extended-release is better than clonidine in regards to efficacy and safety. Clonidine and clonidine extended-release provide additional benefit in improving ADHD symptoms as add-on therapy with psychostimulants. Optimal dosages of clonidine or clonidine extended-release require individualization, whether they are used as monotherapy or in combination with stimulants.

In general, both clonidine and clonidine extended-release were well tolerated. Clonidine was better tolerated in divided doses. The most common side effects were somnolence, fatigue, bradycardia, and hypotension. Electrocardiographic changes were clinically insignificant. However, serious cardiac side effects can occur, especially in individuals with other risk factors. Future studies investigating the long-term effects and safety of clonidine and clonidine extended-release in the treatment of children with ADHD are needed.

\section{Disclosure}

The authors report no conflicts of interest in this work.

\section{References}

1. McDonagh MS, Christensen V, Peterson K, Thakurta S. Drug class review on pharmacologic treatments for attention deficit hyperactivity disorder. Drug Class Reviews. 2009:68-96.

2. Goldman LS, Genel M, Bezman RJ, Slanetz PJ. Diagnosis and treatment of attentiondeficit/hyperactivity disorder in children and adolescents. Council on Scientific Affairs, American Medical Association. JAMA. 1998;279:1100-1107.

3. Dunne JE, Arnold V, Benson S, et al. Summary of the practice parameters for the assessment and treatment of children, adolescents, and adults with ADHD. J Am Acad Child Adolesc Psychiatry. 1997;36:1311-1318.

4. American Psychiatric Association. Diagnostic and Statistical Manual of Mental Disorders (DSM-IV), 4th ed. Washington, DC: American Psychiatric Association; 1994.

5. Keen D, Hadjikoumi I. ADHD in children and adolescents. Clin Evid. 2008; 10:312-343.

6. Sallee FR. The role of alpha2-adrenergic agonists in attention-deficit/ hyperactivity disorder. Postgrad Med. 2010;122:78-87.

7. Pliszka SR. The neuropsychopharmacology of attention-deficit/ hyperactivity disorder. Biol Psychiatry. 2005;57:1385-1390.

8. Arnsten AF, Scahill L, Findling RL. Alpha-2 adrenergic receptor agonists for the treatment of attention-deficit/hyperactivity disorder: emerging concepts from new data. J Child Adolesc Psychopharmacol. 2007; $17: 393-406$
9. Sallee, Floyd R. The role of alpha 2 agonists in the attention deficit/ hyperactivity disorder treatment paradigm. Available from: http://www. medscape.org/viewarticle/577743. Accessed August 14, 2011.

10. Arnsten AF, Mathew R, Ubriani R, Taylor JR, Li BM. Alpha-1 noradrenergic receptor stimulation impairs prefrontal cortical cognitive function. Biol Psychiatry. 1999;45:26-31.

11. De Quervain DJ, Roozendaal B, McGaugh JL. Stress and glucocorticoids impair retrieval of long-term spatial memory. Nature. 1998;394: 787-790.

12. Zhang M, Cai J. Extract of Ginkgo biloba leaves reverses yohimbineinduced spatial working memory deficit in rats. Behav Pharmacol. 2005;16:651-656.

13. Milot MR, Plamondon $H$. Changes in HPA reactivity and noradrenergic functions regulate spatial memory impairments at delayed time intervals following cerebral ischemia. Horm Behav. 2011;59:594-604.

14. Kapvay ${ }^{\mathbb{R}}$ (clonidine hydrochloride extended-release) package insert. Atlanta, NJ: Shionogi Pharma Inc; 2010.

15. Jain R, Segal S, Kollins SH, Khayrallah M. Clonidine extended-release tablets for pediatric patients with attention deficit/hyperactivity disorder. J Am Acad Child Adolesc Psychiatry. 2011;50:171-179.

16. Kollins SH, Jain R, Brams M, et al. Clonidine extended-release tablets as add-on therapy to psychostimulants in children and adolescents with ADHD. Pediatrics. 2011;127:e1406-e1413.

17. Palumbo DR, Sallee FR, Pelham WE, et al. Clonidine for attentiondeficit/hyperactivity disorder: I. Efficacy and tolerability outcomes. J Am Acad Child Adolesc Psychiatry. 2008;47:180-188.

18. Daviss WB, Patel NC, Robb AS, et al. Clonidine for attention-deficit/ hyperactivity disorder: II. ECG changes and adverse events analysis. J Am Acad Child Adolesc Psychiatry. 2008;47:189-198.

19. Cannon M, Pelham WH, Sallee FR, et al. Effects of clonidine and methylphenidate on family quality of life in attention-deficit/ hyperactivity disorder. J Child Adolesc Psychopharmacol. 2009;19: 511-517.

20. Kurlan R, Goetz CG, McDermott MP, et al. Treatment of ADHD in children with tics. Neurology. 2002;58:527-536.

21. Meere JV, Gunning B, Stmerdink N. The effect of methylphenidate and clonidine on response inhibition and state regulation in children with ADHD. J Child Psychol Psychiatry. 1999;40:291-298.

22. Connor DF, Barkley RA, Davis HT. A pilot study of methylphenidate, clonidine, or the combination in ADHD comorbid with aggressive oppositional defiant or conduct disorder. Clin Pediatr (Phila). 2000;39: $15-25$.

23. Hazell PL, Stuart JE. A randomized controlled trial of clonidine and adolescent psychiatry. J Am Acad Child Adolesc Psychiatry. 2003;42: 886-894.

24. Nair V, Mahadevan S. Randomised controlled study - efficacy of clonidine versus carbamazepine in children with ADHD. JTrop Pediatr. 2009;55:116-121.

25. Ziegenhorn AA, Roepke S, Schommer NC, et al. Clonidine improves hyperarousal in borderline personality disorder with or without comorbid posttraumatic stress disorder: a randomized, doubleblind, placebo-controlled trial. J Clin Psychopharmocol. 2009;29: $170-173$.

26. Najjar F, Weller RA, Weisbrot J, Weller EB. Post-traumatic stress disorder and its treatment in children and adolescents. Curr Psychiatry Rep. 2008;10:104-108.

27. Boehnlein JK, Kinzie JD. Pharmacologic reduction of CNS noradrenergic activity in PTSD: the case for clonidine and prazosin. J Psychiatr Pract. 2007;13:72-78.

28. Strawn JR, Geracioti TD Jr. Noradrenergic dysfunction and the psychopharmacology of posttraumatic stress disorder. Depress Anxiety. 2008;25:260-271.

29. Valenca AM, Nardi AE, Mezzasalma MA, et al. Clonidine in respiratory panic disorder subtype. Arg Neuropsiquiatr. 2004;62:396-398.

30. Valenca AM, Mezzasalma MA, Nascimento I, Lopes FL, Zin WA, Nardi AE. Respiratory panic disorder treatment with clonidine. Can J Psychiatry. 2004;49:154. 
31. Donnelly CL. Pharmacologic treatment approaches for children and adolescents with posttraumatic stress disorder. Child Adolesc Psychiatr Clin NAm. 2003;12:251-269.

32. Porter DM, Bell CC. The use of clonidine in post-traumatic stress disorder. J Natl Med Assoc. 1999;91:475-477.

33. Lustig SL, Botelho C, Lynch L, Nelson SV, Eichelberger WJ, Vaughan BL. Implementing a randomized clinical trial on a pediatric psychiatric inpatient unit at a children's hospital: the case of clonidine for post-traumatic stress. Gen Hosp Psychiatry. 2002;24:422-429.

34. Marshall RD, Blanco C, Printz D, Liebowitz MR, Klein DF, Coplan J. A pilot study of noradrenergic and HPA axis functioning in PTSD vs panic disorder. Psychiatry Res. 2002;110:219-230.

35. Lange JT, Lange CL, Cabaltica RB. Primary care treatment of posttraumatic stress disorder. Am Fam Physician. 2000;62:1035-1040.

36. Sallee FR, Richman H, Sethuraman G, Dougherty D, Sine L, AltmanHamamdzic S. Clonidine challenge in childhood anxiety disorder. J Am Acad Child Adolesc Psychiatry. 1998;37:655-662.

37. Kellner M, Yassouridis A, Jahn H, Wiedemann K. Influence of clonidine on psychopathological, endocrine and respiratory effects of cholecystokinin tetrapeptide in patients with panic disorder. Psychopharmacology (Berl). 1997;133:55-61.

38. Kellner M, Wiedemann K. Atrial natriuretic hormone responses to clonidine in patients with panic disorder and in healthy control subjects. Eur J Endocrinol. 1997;137:84-85.

39. Coplan JD, Pine DS, Papp LA, Gorman JM. A view on noradrenergic, hypothalamic-pituitary-adrenal axis and extrahypothalamic corticotrophin-releasing factor function in anxiety and affective disorders: the reduced growth hormone response to clonidine. Psychopharmacol Bull. 1997;33:193-204.

40. Srour M, Lesperance P, Richer F, Chouinard S. Psychopharmacology of tic disorders. J Can Acad Child Adolesc Psychiatry. 2008;17: $150-159$.

41. Du YS, Li HF, Vance A, et al. Randomized double-blind multicentre placebo-controlled clinical trial of the clonidine adhesive patch for the treatment of tic disorders. Aust N Z J Psychiatry. 2008;42:807-813.

42. Qasaymeh MM, Mink JW. New treatments for tic disorders. Curr Treat Options Neurol. 2006;8:465-473.

43. Sandor P. Pharmacological management of tics in patients with TS. J Psychosom Res. 2003;55:41-48.
44. Pringsheim T, Davenport WJ, Lang A. Tics. Curr Opin Neurol. 2003;16: 523-527.

45. Gaffney GR, Perry PJ, Lund BC, Bever-Stille KA, Arndt S, Kuperman S. Risperidone versus clonidine in the treatment of children and adolescents with Tourette's syndrome. J Am Acad Child Adolesc Psyhiatry. 2002;41:330-336.

46. Jiménez-Jiménez FJ, Garcia-Ruiz PJ. Pharmacological options for the treatment of Tourette's disorder. Drugs. 2001;61:2207-2220.

47. Kessler AR. Clonidine treatment increases tics in patients with Tourette syndrome: case report. J Child Neurol. 2001;16:380-381.

48. Scahill L, Chappell PB, King RA, Leckman JF. Pharmacologic treatment of tic disorders. Child Adolesc Psychiatr Clin N Am. 2000;9:99-117.

49. Newcorn JH, Schulz K, Harrison M, DeBellis MD, Udarbe JK, Halperin JM. Alpha 2 adrenergic agonists. Neurochemistry, efficacy, and clinical guidelines for use in children. Pediatr Clin North Am. 1998; 45:1099-1122.

50. Cohen DJ, Riddle MA, Leckman JF. Pharmacotherapy of Tourette's syndrome and associated disorders. Psychiatr Clin North Am. 1992;15: 109-129.

51. Nicholas F. Transient ischemic attack with risperidone and clonidine. J Am Acad Child Adolesc Psychiatry. 2007;46:1530-1531.

52. Feron F, Hendriksen J, Nicolai, J, Vles JSH. New-onset seizures: A possible association with clonidine. Pediatr Neurol. 2008;38: 147-149.

53. Maloney MJ, Schwam JS. Clonidine and sudden death. Pediatrics. 1995;96:1176-1177.

54. Cantwell DP, Swanson J, Connor DF. Case study: adverse response to clonidine. J Am Acad Child Adolesc Psychiatry. 1997;36:539-544.

55. Swanson JM, Flockhart D, Udrea D, Cantwell D, Connor D, Williams L. Clonidine in the treatment of ADHD: Questions about safety and efficacy. J Child Adolesc Psychopharmacology. 2005;5:301-304.

56. Wilens TE, Spencer TJ, Swanson JM, Connor DF, Cantwell D. Combining methylphenidate and clonidine: a clinically sound medication option. J Am Acad Child Adolesc Psychiatry. 1999;38:614-619.

57. Fenichel RR. Combining methylphenidate and clonidine: The role of post-marketing surveillance. J Child Adolesc Psychopharmacol. 1995;5: $155-156$.
Adolescent Health, Medicine and Therapeutics

\section{Publish your work in this journal}

Adolescent Health, Medicine and Therapeutics is an international, peer-reviewed, open access journal focusing on health, pathology, and treatment issues specific to the adolescent age group. All aspects of health maintenance, preventative measures and disease treatment interventions are addressed within the journal and practitioners from

\section{Dovepress}

all disciplines are invited to submit their work as well as healthcare researchers and patient support groups.. The manuscript management system is completely online and includes a very quick and fair peerreview system. Visit http://www.dovepress.com/testimonials.php to read real quotes from published authors. 